\title{
Structured Learning Approach Model (SLA) for Assertive Skills Training in Middle School Students
}

\author{
Mawardi Djamaluddin, Zainab Canu, Asriyani M. Arifin, Hendi Sugianto
}

\author{
IAIN Ternate, Indonesia \\ mawardidjamaluddin@gmail.com
}

Submitted: 2020-04-13, Revised: 2020-04-20, Accepted: 2020-05-23

\begin{abstract}
Communication and social skills are not yet wholly owned by students, so psychological problems often arise, for example, inability to convey wishes to others in a positive way, so that others often ignore matters relating to the rights of students. Therefore, students often place themselves as passive individuals when doing something that is fundamentally incompatible with their needs subjectively. This study aims to develop guidelines for assertive skills training to facilitate junior high school students to develop assertive skills. The research and development model used was adapted from Borg and Gall. Product development has gone through the stages of expert BK assessment and prospective product users. Data were collected using acceptability rating scale instruments. The data analysis technique used is the Inter-Rater Agreement Model. Based on the results of the study, it showed that the assertiveness skills training guide for junior high school students fulfilled the acceptability criteria, which included four aspects, namely the aspects of usefulness, feasibility, accuracy, and compliance.
\end{abstract}

Keywords: Assertive Skills; Counseling Services; Structured Learning Approach Model

\section{Introduction}

Putting oneself as someone who respects the rights of others and also respects the powers possessed by oneself is an attitude that often cannot be done by someone in complementary situations and conditions. This makes a person unable to effectively build social interaction with others, especially in the communication process. Though the role of social interaction is vital in the formation and development of individual traits and characters (Bruning, Schraw, \& Ronning, 1999; Lesgold, 2013; Slavin, 2019). The same phenomenon also occurs in students at the junior high school level who often act passively despite complying with requests from friends who are not by their wishes or being aggressive by asking their friends to obey all their wishes. Therefore, efforts to address problems in interpersonal communication that are passive or aggressive towards the rights of students or others, assertive skills are needed that are expected to give students the skills to express their feelings positively.

Assertiveness is an attitude of courage to claim rights without experiencing fear or guilt, without violating the rights of others (Alberti \& Emmons, 2017). Assertive behavior is also an expression of the feelings, thoughts, needs, and rights of individuals directly and honestly without the existence of unwarranted anxiety (Cawood, 1992). The results of previous studies indicate that assertive skills can improve effective interpersonal communication between individuals and reduce the risk of anxiety and stress (Bulantika \& Sari, 2019; Oktafisa Al'ain, 2013). Assertive behavior impacts on various aspects of life, namely personal, social, learning, and career aspects.

Each student has a variety of ways of showing assertiveness towards behavioral responses to their peers. Students who have low assertiveness will face difficulties in expressing what is thought and felt proportionally or based on the norms prevailing in the society. This statement is supported by research, which states that other impacts experienced by individuals when they do not have an assertive attitude will be difficult to communicate with people around them because they cannot express their feelings and feel pressured by their feelings (Leroy, 2020; Ward \& Holland, 2018; Žnidaršiè \& Zupan, 2019). 
This is because there are significant differences between assertiveness, aggression, and passivity. These three forms of behavior are distinguished in attitudes displayed by individuals. Assertive individuals can assert their rights without compromising the rights of others, respecting themselves and others, and creating an atmosphere of communication with honesty and openness. Also, the characteristics displayed by individuals who behave aggressively can be seen from the attitude of students in asserting their rights without considering the rights of others, can express their feelings without hurting others. While passive behavior is behavior that fails to submit its reasons, is inhibited in expressing emotions and desires to meet the demands of others (Johnston, 2013; West \& Beck, 2018).

Assertive skills are proven to provide the ability fr students to control their desires and manage attitudes in response to influences arising from outside themselves, especially those that have the potential to affect student self-development adversely. This is consistent with the results of research that show that assertive skills can control students to regulate behavior in the learning process without regard to interference from people around and have an attitude of adherence to existing norms (Dewantari \& Izzaty, 2018). Assertive skills are relevant for students who have high cohesiveness with surrounding individuals because the dynamics that arise in interpersonal relationships are personal and social, students show the attitudes not only have consequences for students but can build the perception of others.

In general, assertive skills training has been developed using different approaches and skills components at various levels of education. The development of assertive training has become one of the right media that can be used by counselors to conduct counseling guidance services (Erlinda, 2011). One learning model that can be developed for assertive skills training is a structured learning approach (SLA). Structured learning approach model is one of the models of learning theory and behavior modification using behavior change techniques and individual reactions to the improvement of specific skills (Sprafkin, Gershaw, \& Goldstein, 1993).

The application of the modified SLA is useful to improve the social sharing skills of students at the elementary school level who are unable to complete the educational process on time, the application of the modified SLA model also shows that students in the at-risk children category can be more open in telling the experiences they have (Wahyu, Ardyanti, Hitipeuw, \& Ramli, 2017).

Structured learning approach has four kinds of hierarchical components that can help improve new behaviors, namely (1) modeling, (2) role-playing, (3) performance and feedback and (4) transfer of training and maintenance (Goldstein, Sprafkin, Gershaw, \& Klein, 1980; Sprafkin et al., 1993). Through the Structured Learning Approach (SLA) component, students are actively involved in every assertive training. So by using a structured learning approach, students' assertive skills can develop and be internalized within students to be implemented in daily life.

Counselors have a vital role in improving students' assertive skills because the learning process will only succeed if students are in a comfortable and conducive atmosphere in the optimal developmental stage, especially in the context of interpersonal relationships with friends at school. The guidance and counseling function is one of the development functions that play a role in developing all the potential possessed by students which includes personal, social, learning, and career fields as well as overcoming difficulties faced by students in learning, adjusting to the educational environment, the community environment, and the work environment (Rahardjo \& Zamroni, 2017). But what happens in school counselors still have many roles. Besides, the implementation of functions and the goals of guidance and counseling are not optimal.

This research was conducted to develop guidelines for assertive skills training for junior high school students who can improve the assertive skills of junior high school students. 
Students cause this often find obstacles in interpersonal relationships as a result of students not having assertive skills. The importance of assertive skills training for students is also supported by the opinion that individuals who do not have assertive skills in the context of interpersonal communication can weaken interpersonal relationships with others so that it has the potential to increase stress (stress) in the form of interpersonal conflict that results in loss of social support from people around the individual (Eslami, Rabiei, Afzali, Hamidizadeh, \& Masoudi, 2016). Often people misinterpret when communicating with others, especially when showing assertiveness in the form of rejection. It is considered rude behavior so that in teaching assertive skills, it needs to be adjusted to the socio-culture owned by the local community. Therefore, students need to be trained to show positive, assertive skills in interpersonal communication with others.

\section{Methods}

Assertive skills training guidelines for junior high school students were developed, including expert BK assessments and product user prospective assessments. The BK expert assessment was carried out by three guidance and counseling experts who assessed the acceptability scale of the developed guide. Meanwhile, the assessment by prospective product users was carried out by three school counselors who also assessed the acceptability scale of the developed guide. This research method was adapted from the Research and Development approach of Borg and Gall. The steps are: 1) Conducting a preliminary study; 2) Planning; 3) Develop initial product prototypes; 4) Carry out initial field trials; 5) Revise the product; 6) Carry out small group trials; 7) Revise operational products; 8) Carry out functional field tests; 9) Revise the final product; 10) Compile the final product of the assertiveness skills training guide that aims to develop junior high school students' assertive skills (Gall, Gall, \& Borg, 2003).

In the first stage, a BK expert test is conducted, and the next step is a product user prospective test. Data obtained from expert BK assessments are used to make improvements to the guidelines developed before they are given to prospective product users to provide assessments. Activities carried out by BK experts and prospective product users in the assessment stage are to fill in the acceptability scale questionnaire for assertive skills training guidance. Indicators of acceptability scale guidelines for assertive skills training include aspects of usefulness, feasibility, accuracy, and appropriateness. The inter-rater agreement model data analysis technique is done by calculating the level of agreement of BK experts and testing prospective product users. The data is also analyzed qualitatively by reviewing the inputs by BK experts and prospective product users on the criticism sheet and suggestions on the questionnaire scale of the acceptability guide's guide assertive skills training, then made into consideration in revising the products developed.

\section{Results and Discussion}

The final product produced by the research was the development of assertive skills training guidelines for junior high school students, there were three assertive skills training books, namely assertive skills training books for counselors, assertive skills training books for students, and assertive skills guidance handbooks. The development of assertive skills training guides for junior high school students has gone through several assessment processes and revision processes. The assessment is carried out by BK experts and potential product users (school counselors).

Assertive skills training books for students are arranged systematically with stages of training steps based on a structured learning approach model consisting of general objectives, specific objectives, and scenarios of training activities. The assertive skills training manual for counselors consists of an introduction, general training instructions, and training procedures. 
Meanwhile, the material for the guide book on assertive skills training consists of an introduction and a collection of training materials.

The results of the development product in the form of an assertive skills training manual for counselors and students, this assertive skills training material refers to the assessment of guidance and counseling experts who are part of the research and development model stages related to conducting small group trials. The expert judgment technique used is the inter-rater agreement. Data from BK expert test results related to acceptability aspects of assertive skills training guidelines can be seen in table 1 .

Table 1. Level of expert BK agreement

\begin{tabular}{cccc}
\hline $\begin{array}{c}\text { Acceptability } \\
\text { Aspects }\end{array}$ & $\begin{array}{c}\text { Number of } \\
\text { Aspects of } \\
\text { Agreement } \\
\text { (Item) }\end{array}$ & Average Percentage & Classification \\
\hline Usability aspect & 10 statements & $66.67 \%$ & High \\
\hline $\begin{array}{c}\text { The feasibility } \\
\text { aspect }\end{array}$ & 8 statements & $66.67 \%$ & High \\
\hline $\begin{array}{c}\text { The accuracy } \\
\text { aspect }\end{array}$ & 20 statements & $100 \%$ & Very high \\
\hline $\begin{array}{c}\text { The propriety } \\
\text { aspect }\end{array}$ & 4 statements & $100 \%$ & Very high \\
\hline
\end{tabular}

Data from the expert test assessment results were analyzed using the inter-rater agreement model, the results obtained for the assessment of the assertive skills training guide were $66.67 \%$ of the experts assessed that the training guidelines were useful, the expert provided a percentage of $66.67 \%$ assessment for the feasibility assessment aspects shows that the training guide developed is feasible, for the aspect of appropriateness assessment, the expert assertive skill training guide gives a percentage of $100 \%$ which means that the training guide developed is very feasible, and the expert also provides a percentage with the assessment of $100 \%$ for the appropriateness aspect which shows that the assertive skills training guide that has been developed is very appropriate.

Besides, in the small group trial stage, the counselor, as a potential user of the product, also provides an assessor related to the acceptability aspect of the development of assertive skills training guidelines, which can be seen in table 2 .

Table 2. Level of the agreement for prospective product users (counselors)

\begin{tabular}{cccc}
\hline $\begin{array}{c}\text { Acceptability } \\
\text { Aspects }\end{array}$ & $\begin{array}{c}\text { Number of } \\
\text { Aspects of } \\
\text { Agreement } \\
\text { (Item) }\end{array}$ & Average Percentage & Classification \\
\hline Usability aspect & 10 statements & $66.67 \%$ & High \\
\hline $\begin{array}{c}\text { The feasibility } \\
\text { aspect }\end{array}$ & 8 statements & $66.67 \%$ & High \\
\hline $\begin{array}{c}\text { The accuracy } \\
\text { aspect }\end{array}$ & 20 statements & $66.67 \%$ & High \\
\hline $\begin{array}{c}\text { The propriety } \\
\text { aspect }\end{array}$ & 4 statements & $66.67 \%$ & \\
\hline
\end{tabular}

Three counselors conducted the product test, the data of the product test assessment results were analyzed using the inter-rater agreement model, the results obtained for the assessment of the assertive skills training guide were the average prospective product users 
giving a percentage of $66.67 \%$ assessment for the aspect of usability, training guidelines which show that the developed guide is useful, on average prospective product users provide a percentage of $66.67 \%$ assessment for the feasibility aspect. This assertive skills training guide shows that the developed guide is feasible. Prospective product users also, on average, give a percentage of $66.67 \%$ assessment for aspects of the accuracy of the assertive skills training guide, which shows that the guidelines developed are appropriate. Meanwhile, on average, the average prospective product user gives a percentage assessment of $100 \%$ for the appropriateness of the assertiveness skills training guide, which shows that the guidelines developed are very appropriate. Based on the results of assessments from BK experts and prospective product users, it shows that the guidance and counseling service instruments in the form of assertive skills training guidelines for junior high school students meet the acceptability criteria. The following data are obtained from the BK expert candidate tests and prospective product users:

Based on table 2, there is a difference in classification between the level of agreement of $\mathrm{BK}$ experts and prospective product users in providing assessments related to the acceptability of assertive skills training guidelines. Overall, there are differences in the classification of agreement levels for the aspects of accuracy and propriety. BK experts give a percentage of $100 \%$ for the aspect of accuracy with very high classification and provide a percentage of $100 \%$ also for aspects of propriety with very high classification. Meanwhile, prospective product users gave a percentage of $66.67 \%$ for the aspect of accuracy with high classification and gave a percentage of $66.67 \%$ for the aspect of propriety with high classification. It can be concluded that the assertiveness skills training guide for junior high school students meets the admission criteria and can be used in the training process.

Qualitatively (through interviews), some BK experts and potential product users consider that the language used is less clear/complicated, and generally assesses the need for media variations in providing training. Based on this input, a revision is made based on the feedback given by the BK experts and prospective product users. Changes were made to writing techniques and media variations in providing training to make it more interesting for junior high school students.

Based on the results of expert assessments and prospective users, the development of assertive skills guidelines using the SLA model has fulfilled all components of the acceptance aspect based on the results of the inter-rater agreement model. Assertive skills are an essential factor that must be mastered for junior high school students. The importance of assertive skills for students is also supported by the opinion that individuals who do not have assertive skills in the context of interpersonal communication can weaken interpersonal relationships with others so that it has the potential to increase the pressure in the form of interpersonal conflict resulting in loss of social support from people around the individual (Eslami et al., 2016). This shows that the usability aspect of development is achieved.

Assertive attitudes form appropriate social skills for various social situations, through assertiveness giving responses that are relevant and consistent with the demands of the social context. Assertiveness can be demonstrated by giving and receiving affection, giving praise, being able to give and receive criticism, giving or rejecting requests, the ability to discuss problems, argue, and negotiate (Alberti \& Emmons, 2017). Assertive relates to behavior in interpersonal relationships characterized by the ability of a person to express thoughts, feelings, and beliefs that are shown directly, honestly, precisely, and do not violate the rights of others (Larsen \& Jordan, 2017). Thus, assertive training using the structured learning approach model provides provisions for students to behave by their desires without hurting or hurting others.

Assertive training is a systematic summary of skills, regulations, concepts or attitudes that can help develop and practice the ability of individuals to convey their thoughts, feelings, desires honestly, and needs with confidence so that they can relate well to the social 
environment (Golden, 2002; Ramadhini \& Santoso, 2019). Therefore, in the training of assertive skills that are developed this meets the aspects of accuracy in the content or material provided, there are five components of assertive skills that are trained to students, namely: (1) Skills for asking permission; (2) Negotiation skills; (3) Skills of helping others; (4) Skills using self-control; and (5) sharing skills. Assertive skills training is a place to train and familiarize students with assertive behavior in their daily relationships with those around them (Herman, Nurshal, \& Novrianda, 2020; Leroy, 2020; Mamedova, Kobazova, \& Shakhmalova, 2020). In training, students are trained to learn assertive responses in various situations by using the integrated approach, namely by practicing integrated assertive skills relating to simple assertive responses in general conditions, to more complex interventions in more specific cases. Assertive training is also used to reduce negative conformity to peer groups in junior high schools that are designed through 5 meetings (Selfi, 2017).

The Structured Learning Approach model used in this study is by the aspects of the age of relatively young students, with the consideration that through the structured training stages, it can make it easier for students to follow each step in trainingSLA in this development uses standards that have been determined in the learning process that emphasizes the need for the habit of responding and imitating. This is consistent with the results of research which state that the SLA provides specific standards in the learning process so that human behavior is not the result of reflexes on a given stimulus, but rather the reactions that arise due to interactions that occur between the environment and social cognitive itself (Latifah, 2016).

Assertive training with the SLA model provides direction for students to behave assertively so that later, students will get feedback and apply assertiveness in their lives. The more assertive students are, the better these students will be in creating friendships, students can explain things they want to their friends correctly, effective communication between friends will emerge. This way of communication will be able to provide positive encouragement in student friendship. Conversely, students who are not / are less able to express their desires correctly will tend to have low-quality bonds, and when this happens, problems that arise will increase (Dinata, Murtini, \& Safaria, 2019). Assertive skills are not something that has existed since birth, so to form and accustom students to assertive behavior requires assertive training that is gradual and should begin at an early age. This is evident from the results of the BK expert agreement and prospective product users. They consider that assertive skills training guidelines are classified as useful and appropriate to be given to junior high school students.

\section{Conclusions and Suggestions}

Based on the results of the study concluded that the description of the theory and the suitability of training steps generally meet the acceptability assessment, which means useful, appropriate, feasible, and should be used as an intervention in the development of assertive skills of students. Counselors are expected to understand the study of the steps in the training process before providing guidance and counseling services. Counselors are expected to thoroughly review assertive skills training guidelines, which include counselor books, student books, and material books. The training manual also needs to be modified for guidance and counseling services for students with different levels of education, taking into account the characteristics of students.

\section{References}

Alberti, R., \& Emmons, M. (2017). Your perfect right: Assertiveness and equality in your life and relationships. new harbinger publications.

Bruning, R. H., Schraw, G. J., \& Ronning, R. R. (1999). Cognitive psychology and instruction. ERIC. 
Bulantika, S. Z., \& Sari, P. (2019). The Effectiveness of Assertive Training Techniques and Thought-Stopping Techniques to Increase Student Assertiveness Ability. Biblio Couns: Jurnal Kajian Konseling Dan Pendidikan, 2(3), 109-116.

Cawood, D. (1992). Assertiveness for managers: Learning effective skills for managing people. North Vancouver, BC: Self-Counsel Press.

Dewantari, T., \& Izzaty, R. E. (2018). Assertive Training On Discipline of Learning in Junior High School. The International Journal of Counseling and Education Vol, 3, 57-62.

Dinata, A. N., Murtini, M., \& Safaria, T. (2019). Peran peer acceptance dan perilaku assertif pada keterampilan sosial remaja. Prosiding Seminar Nasional Magister Psikologi Universitas Ahmad Dahlan, 327-334.

Erlinda, M. (2011). Pengembangan Panduan Pelatihan Keterampilan Asertif Siswa SMP.(Tesis). DISERTASI Dan TESIS Program Pascasarjana UM.

Eslami, A. A., Rabiei, L., Afzali, S. M., Hamidizadeh, S., \& Masoudi, R. (2016). The effectiveness of assertiveness training on the levels of stress, anxiety, and depression of high school students. Iranian Red Crescent Medical Journal, 18(1).

Gall, M. D., Gall, J. P., \& Borg, W. R. (2003). Educational Research. Educational Research: An Introduction.

Golden, L. S. (2002). Evaluation of the efficacy of a cognitive behavioral program for offenders on probation: Thinking for a Change. University of Texas Southwestern Medical Center at Dallas Dallas.

Goldstein, A. P., Sprafkin, R. P., Gershaw, N. J., \& Klein, P. (1980). Skillstreaming the adolescent: A structured learning approach to teaching prosocial skills. Research Press Company.

Herman, H., Nurshal, D., \& Novrianda, D. (2020). The Effect of Assertive Training on Bullying in Junior High School. Jurnal Keperawatan Soedirman, 15(1).

Johnston, A. I. (2013). How new and assertive is China's new assertiveness? International Security, 37(4), 7-48.

Larsen, K. L., \& Jordan, S. S. (2017). Assertiveness Training. In Encyclopedia of Personality and Individual Differences (pp. 1-4). Springer, Cham.

Latifah, L. (2016). Pengembangan Buku Panduan Penyesuaian Diri di Lingkungan Kerja Menggunakan Metode Structured Learning Approach (SLA) Bagi Siswa SMK. DISERTASI Dan TESIS Program Pascasarjana UM.

Leroy, C. (2020). The Importance of Personal Effectiveness Training in University Master Courses: The Role of High School in Students' Assertiveness and Self-Awareness Development. In Handbook of Research on Operational Quality Assurance in Higher Education for Life-Long Learning (pp. 133-165). IGI Global.

Lesgold, A. (2013). Cognitive psychology and instruction (Vol. 5). Springer Science \& Business Media.

Mamedova, L. V, Kobazova, Y. V, \& Shakhmalova, I. J. (2020). Psychological and Pedagogical Methods for Development of Assertive Behavior in High School Students. In International Scientific Conference" Far East Con"(ISCFEC 2020) (pp. 2117-2123). Atlantis Press.

Oktafisa Al'ain, M. (2013). Pelatihan Asertif Untuk Meningkatkan Komunikasi 
Interpersonalanggota Hima (Himpunan Mahasiswa) Prodi Psikologi FIP. Character: Jurnal Penelitian Psikologi., 2(1).

Rahardjo, S., \& Zamroni, E. (2017). Teori dan Praktik Pemahaman Individu Teknik Testing. Badan Penerbit Universitas Muria Kudus.

Ramadhini, P. S., \& Santoso, M. B. (2019). Assertveness Training Untuk Meningkatkan Kepercayaan Diri Narapidana Remaja. Prosiding Penelitian Dan Pengabdian Kepada Masyarakat, 6(2), 169. https://doi.org/10.24198/jppm.v6i2.21905

Selfi, S. (2017). Penerapan Teknik Assertive Training dalam Mereduksi Konformitas Negatif terhadap Kelompok Sebaya di SMP Negeri 1 Sungguminasa Kabupaten Gowa. UNIVERSITAS NEGERI MAKASSAR.

Slavin, R. E. (2019). Educational psychology: Theory and practice.

Sprafkin, R. P., Gershaw, N. J., \& Goldstein, A. P. (1993). Social skills for mental health: A Structured Learning approach. Allyn \& Bacon.

Wahyu, A., Ardyanti, T., Hitipeuw, I., \& Ramli, M. (2017). Structured Learning Approach ( Sla ) Modification To Improve Sharing Skills of At-Risk Students. European Journal of Education Studies, 3(7), 361-376. https://doi.org/10.5281/zenodo.819481

Ward, C., \& Holland, S. (2018). Assertiveness: A Practical Approach. Routledge.

West, R., \& Beck, C. S. (2018). The Routledge Handbook of Communication and Bullying. Routledge.

Žnidaršiè, J., \& Zupan, N. (2019). Assertiveness, perceived importance and communication skills among students and young graduates in Slovenia and FYR Macedonia. Journal of Human Resource Management, 22(1), 21-29. 